$<$ 症例報告 $>$

興味ある経過をたどった高齢者大腿へルニア嵌頓の一治験例

\author{
竹内 邦夫 岡村 明彦 長嶋起久雄
}

\begin{abstract}
＜要＼cjkstart約＞今回興味ある経過をたどった高齢者大腿へルニア嵌頓の 1 治験例を経験したので報告す る. 症例は, 94 歳, 女性. 左大腿骨頭置換術後リハビリ目的にて近医入院中, 平成 5 年 10 月 27 日腹部不 快感あり，10月28日腹満，嘔吐出現．10月29日イレウスと診断され当科に紹介された．腹満著明で，右 鼠径部にピンポン玉大の弾性軟の有痛性腫瘤を触知し, 右大腿ヘルニア嵌頓によるイレウスの診断にて 入院となった. 緊急手術を勧めるも本人がかたくなに拒否をしたため, イレウス管, 輸液等にて保存的 に治療を進めつつ, 説得を続けた，イレウスは改善せず全身状態にも大きな変化はなかったが, 第19病 日ようやく説得に応じ, 腰麻下にて手術を施行した，開腹すると，血性の腹水を中等量認めた．回腸が 大腿管を通って嵌頓し, 完全に閉塞していた。嵌頓した腸管は虚血性の変化を起こしていたが, 壊死に は宿っていなかった。嵌頓した腸管を約 $10 \mathrm{~cm}$ 切除し端々吻合を行いへルニア門を閉鎖した。術後第 7 病 日より経口摂取を開始した。経過は良好だったが, 高齢でなおかつ右大腿骨頝部骨折術後故, 離床不可 能となり, 術後第77病日に紹介医に転院となった。へルニア嵌頓が還納できなければ一般的には緊急手 術の適応である。しかし本症例では患者自身が手術を拒否したため保存的に経過観察をせざるを得な かったが, 好ばり強い説得により入院後第19病日に手術を承諾したため直ちに手術を施行した. 嵌頓し た腸管は壊死には陥っていなかった。そのため全身状態はそれ程悪化せず救命し得たと思われた。本症 例は医師と患者との間のインフォームド・コンセントの確立に苦労したが，示唆に富む症例と考え若干 の文献的考察を加え報告した。
\end{abstract}

Key words : 高齢者, 嵌頓ヘルニア, 大腿ヘルニア, インフォームド・コンセント

\section{緒言}

大腿ヘルニアは高齢の女性に多く，嵌頓をきたしや す(尚ため,しばしばイレウス症状で来院し, 緊急手術 の適応となることが多い. 今回, 著者らは腹満, 嘔吐 を主訴に来院した大腿へルニア嵌頓例を経験したが, 患者自身が手術を拒否したため, 緊急手術を行い得な かった。しかし第19病日手術を承諾し, 腰麻下に根治 術を行い得た。高齢者ではあったが,腸管が壊死に陥っ ていなかった為に全身状態がそれ程悪化することなく 治癒退院できた。臨床経過上興味深い症例と思われ報 告する.

\section{症例}

患者：94歳，女性.

主訴：腹満, 嘔吐.

既往歴：平成 5 年 1 月, 左大腿骨頝部骨折にて左大

K. Takeuchi, A. Okamura, K. Nagashima：群馬大 学医学部附属病院草津分院外科

受付日：1994.10。3，採用日：1995.2。6
腿骨頭置換術施行.

家族歴：特記すべきことなし。

現病歴：左大腿骨頭置換術後リハビリ目的にて近医 入院中, 平成 5 年 10 月 27 日腹部不快感あり, 10 月 28 日 腹満, 嘔吐出現。10月29日症状増悪し, 腹部単純 X 線 写真でイレウスと診断され，同日当科に紹介. 右大腿 ヘルニア嵌頓によるイレウスの診断にて同日入院と なった。

入院時現症 : 意識清明なるも顔面は苦悶状を呈して いた. 眼球結膜, 眼瞼結膜に黄疸, 貧血は認められな かった. 右鼠径勒带下方にピンポン玉大で弾性軟の有 痛性腫瘤を触知した。腹部は著明に緊満し, 腹壁には 腸管ループが触知された.グル音は metallic sound で あった。

入院時検査所見 : $\mathrm{RBC} 320 \times 10^{4} / \mathrm{mm}^{3}, \mathrm{Hb} 11.3 \mathrm{~g} /$ $\mathrm{d} l$ と軽度の貧血を認めた。 WBC $4,900 / \mathrm{mm}^{3}$, 核の左 方移動は認められなかったが, CRP $2.8 \mathrm{mg} / \mathrm{d} l$ と陽性 であった，血清総蛋白 $5.7 \mathrm{~g} / \mathrm{d} l$, 血清鉄 $21 \mu \mathrm{g} / \mathrm{d} l$, 血清 カルシウム $7.6 \mathrm{mg} / \mathrm{d} l$ と低下していたが, $\mathrm{CPK}, \mathrm{LDH}$ は正常範囲内であった。C 型肝炎抗体, 便潜血反応は陽 


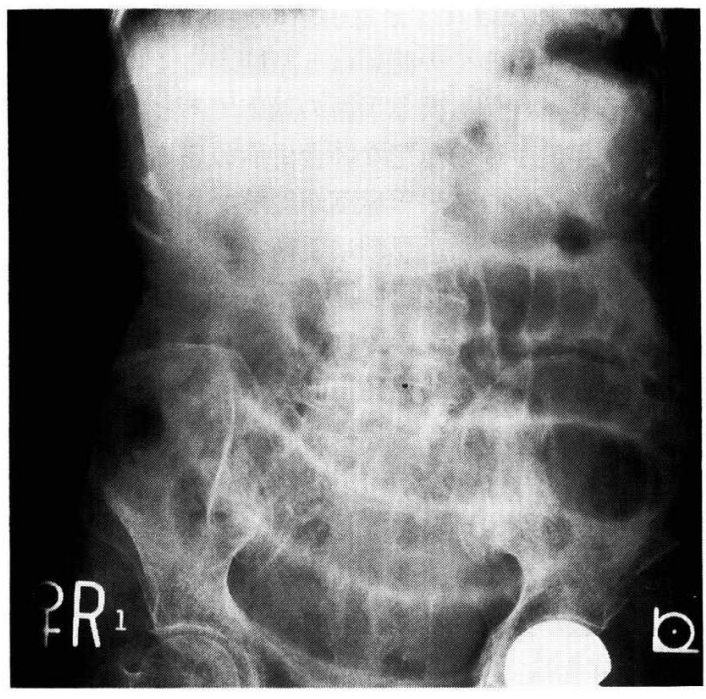

図 1 入院時腹部単純 $\mathrm{X}$ 線写真

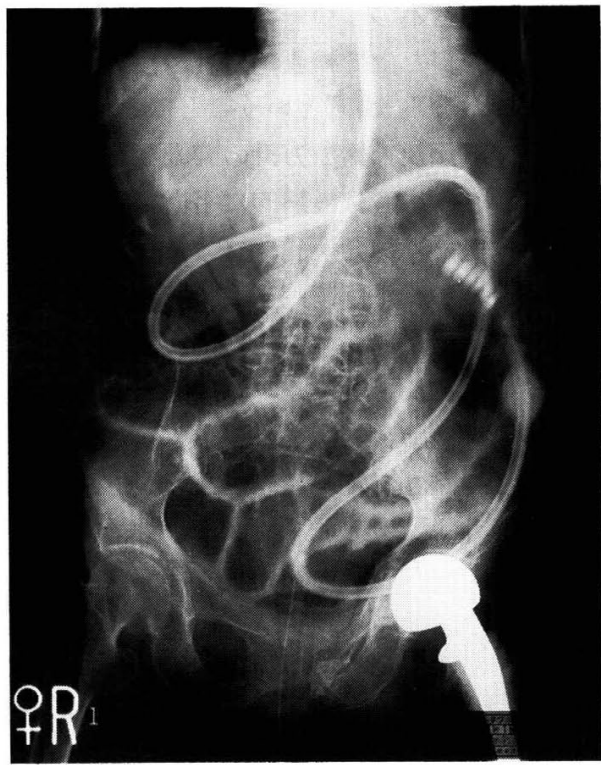

図 2 入院後第 18 病日の腹部単純 X 線写真

性であった。超音波検査では, 腫嵧は cystic pattern を 呈しており，内容物は腹腔内との交通性を示さなかっ た。腹部単純 X 線写真では小腸ガスを多量に認めイレ ウスの所見を吕していた（図1）。

入院後経過：右大腿へルニア嵌頓によるイレウスの 診断にて緊急手術を勧めるも前年度，大腿骨頭置換術 の際肺炎を併発し，死に瀕したため手術に対する恐怖 心が強く，患者自身がかたくなに手術を拒否したため

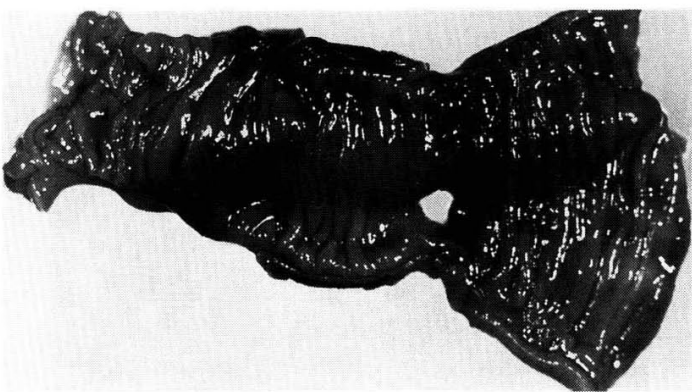

図 3 切除標本所見：穿孔は手術操作によるものであ る。

経過をみた。しかし湢吐の頻度が増してきたため第 3 病日イレウス管を留置し減圧をはかり, 輸滩等にて保 存的に経過をみつつ, 手術を説得し続けた。この間に 腫瘤部の圧痛は消失した。 11月16日の腹部単純 X 線写 真（図 2) では小腸ガスに大きな変化はなく, 疝痛発 作も時に出現し，イレウスは改善傾向になかった。ま たいつまでも経口攝取ができず，さらにはイレウス管 の嫌悪感もあり, 第19病日ようやく手術を承諾し, 腰 麻下に手術を施行した。

手術所見：大腿ヘルニア颃頓で発症後19日も経てお り腹腔内の精査を考慮し，下腹部横切開で開腹した。 やや血性の腹水を中等量認めた，回腸が大腿管を通つ て嵌頓し，同部で完全に閉塞しており口側腸管は著明 に拡張していた．また肛門側の回腸は廃用菱縮から細 くなっていた，嵌頓した腸管はへルニア門部で瀻維性 に強固に癒着しており整復は不可能なため鋭的にへル ニア門部で剝離し還納できた．嵌頓した腸管は約 $6 \mathrm{~cm}$ と短く虚血性の変化を起こし細小となっていたが, 壊 死には陥っていなかった。ヘルニア襄内に血性の腹水 を認めた。嵌頓を解除する際，人工的に穿孔をおこし， また掞頓解除後も腸管の虚血の回復がみられず腸管は 細小であったため，嵌頓した腸管を含め約 $10 \mathrm{~cm}$ を切 除し,端々吻合で再建後, ヘルニア門を McVay 法にて 閉鎖した。

切除標本：粘膜は浮腫性ではあるが壊死性変化はな く, 腸壁は全体に肥厚していた(図 3 ). 組織学的には 粘膜下にうっ血, 強い浮腫, 軽いリンパ球浸潤を認め た。筋層は一部断裂し，奬膜下は繊維化のため著明に 肥厚し,リンパ球浸潤とうっ血, 浮腫を認めた。また 筋層と墏膜下に一部変性壊死を認め, 同部に単核組織 球，多核巨細胞，毛細血管の増生を認めた（図 4). 術後経過：術後第 7 病日より経口捸取を開始した。 


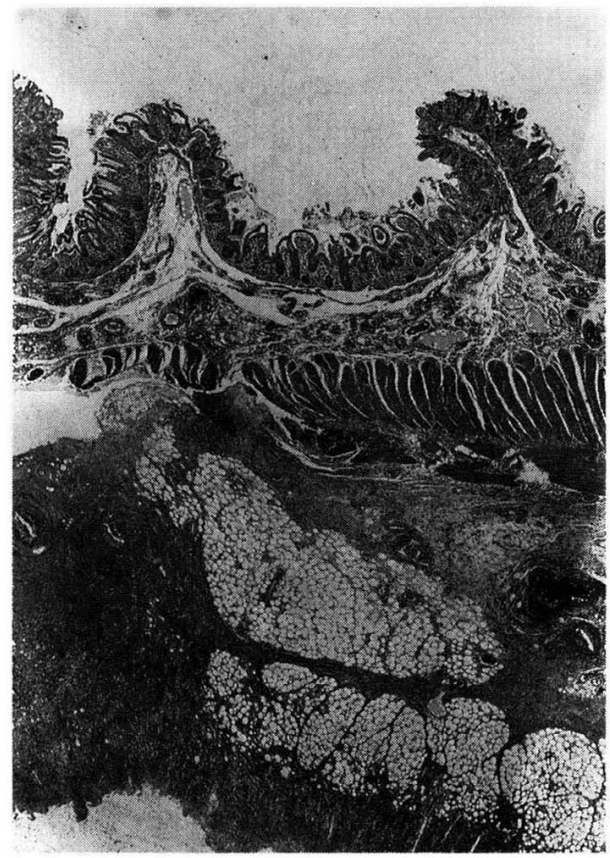

园4 病理所見 (H.E. 染色, $\times 40)$

高齢と左大腿骨䅡部骨折後故，離床はなかなか進まな かった．経口掑取は短期間で良好になったが，結局離 床できず，また家庭の事情から自宅退院は不可能とな り，術後第77病日に紹介医に転院となった。

\section{考察}

大腿へルニアは60歳代を中心とした高齢の女性に多

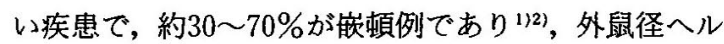
ニアに比べ嵌頓の頻度が高い3．高政者の中には, 鼠径 部局所の訴えは軽度あるいは全くなくイレウス症状を 主訴に来院することがあり ${ }^{2}$, 開腹既往のないイレウ ス症例では, ヘルニア嵌頓によるイレウスの可能性も 考え鼠径部を入念に診察する必要がある。一般的には 嵌頓後 6 時間以上経過している症例に対してはあまり 無理な還納をしない方がよいとされており ${ }^{3)}$, 本症例 も嵌頓後 1 日以上経過しており，無理な還納は行わな かった。また，腸管壁の一部が佽頓する Richter 型へル ニア嵌頓の場合にはイレウス症状を呈さないことがあ るので手術の時期を失しないよう注意が必要である。 田中ら"は18例の嵌頓症例中 7 例 (39\%) が Richter 型 であり，そのうち 4 例 (22\%) に腸管壊死を認め， 2 例（11\%）が死ししたと報告しており，早期診断と早 期手術が必要と思われる。一般的には嵌頓した腸管が
用手還納されなければ緊急手術の適応であり，饗場5) は発病から手術までの時間は 5 時間から 4 日間と報告 している. 本症例も緊急手術の適応であったが，患者 自身が前年度手術の重篤な肺合併症の恐怖と嵌頓へル ニアによるイレウスの重症度が理解できなかったため か手術を拒否したため早期に手術を行うことができな かった。結果的には嵌頓した腸管が約 $6 \mathrm{~cm}$ と短いうえ に局所の限局性腹膜炎のみにとどまり，循罟障害がそ れ程強くなかったために19日間という長期にわたり鼠 径部腫瘤の局所の炎症所見はみられず，腹膜刺激所見 も出現せずにイレウスとして保存的に経過観察しえ た。また切除標本で墏膜下に炎症性の肉芽組織が形成 されていることより, 病理組織学的にもへルニアの嵌 頓した状態が比較的長期にわたり続いたことを示唆し ている.

インフォームド・コンセントとは，我が国では説明 と同意と訳され゙)，その意味するところは“医師が計画 する全ての医療行為の一つ一つに対して患者が了解・ 納得し，承諾を得た上で検查，処理，投薬そして手術 が行わなければならない”ということである”．本症例 では，医師の病態及び治療方針の詳細な説明とねばり 強い説得により，患者は最終的に手術に同意した。

高秢者では術前の併発疾患, 重要臟器障害も高率で, 術後の合併症も多く,手術手技上依然として high risk 患者とみなすべきである ${ }^{8)}$. 特に80歳以上の高齢者は 心肺その他の合併疾患が多く，気管内括管による全身 麻酔では, 術後の肺合併症や心疾患への負担が奬念さ れ, 腰椎硬膜外麻酔や局所麻酔を選択することが多 い9). 本症例も94歳という高齢のため, 腰椎麻酔で行っ た.

\section{文献}

1）棚瀬晾太郎, 牧野永城：大腿へルニア. 新外科学大 系，25B(水本誠二，他編)，中山書店，東京，1990， p92-105.

2）冲永功太：大䀶ヘルニア. 外科診療 $1993 ； 21$ : $565-571$

3）三重野寛治：嵌頓ヘルニア. 臨床外科 $1988 ; 43$ ： 1049-1055.

4）田中千凱, 伊藤隆夫, 大下祐夫：大眼へルニア嵌頓 による絞扼性イレウス症例の検討. 腹部救急診療 の進歩 $1992 ; 12: 291-295$.

5）饗庭庄一：大腿へルニア．臨床外科 $1988 ； 43$ ： $1071-1079$. 
6）恩田昌彦, 松倉則夫：インフォームド・コンセント の問題点. 腹部救急診療の進歩 $1992 ; 12: 815$ 819.

7）篠田知璋：インフォームド・コンセント.PT ジャ ーナル $1993 ; 27: 4-8$.

8）林 志郎：高齢者の術後 Cure とCare一その問題
点と目標一. Geriatric Medicine 1992; $30: 1383$ $-1386$

9）大澤二郎, 東出俊一, 田中 誠, 伊東正文, 白波瀬 功, 網 政明, 他：高歯者単径へルニアーその問題 点と治療のポイントー. 臨床外科 $1988 ; 43: 1039$ -1048 .

Abstract

\title{
A Case of Incarceration of a Right Femoral Hernia in a Very Old Female with a Intriguing Clinical Course
}

\author{
Kunio Takeuchi, Akihiko Okamura and Kikuo Nagashima
}

The patient was a 94-year-old woman. She was admitted on our hospital for ileus due to incarceration of a right femoral hernia on October 29, 1993. Although an emergency operation was necessary she refused, therefore we continued to have conservative therapy. After repeated persuation, she agreed the operation which was performed under spinal anesthesia on November 17. The peritoneal cavity was opened through a transverse incision of the lower abdomen. Some bloody ascites was encountered. Part of the jejunum was incarcerated

Department of Surgery, Gunma University Kusatsu Branch Hospital through right femoral canal and was completely obstructed, with ischemic but no necrotic changes. It was excised. She resumed oral intake on the 7 th postoperative day and was discharged on the 77th postoperative day. Initially due to her opposition we could not perform the operation, but after persistent persuation she aggreed and survived. Good communications between the doctor and the patient, and of course informed consent, was very important in such cases.

Key words: Incarceration of femoral hernia in the aged, Informed

(Jpn J Geriat 1995; 32: 292-295.) 